\title{
Mapping Television Shows that are of Favored by Elementary School Students
}

\author{
Atiqa Sabardila ${ }^{*}$, Markhamah², Zainal Arifin' ${ }^{3}$, Hari Kusmanto ${ }^{4}$, Lathifah Nurul \\ Hidayah $^{5}$, Anita Dewi Kurniasari ${ }^{6}$, and Duwi Saputro ${ }^{7}$
}

1,2,3,4,5,6,7 Master of Indonesian Language Education, Muhammadiyah University of Surakarta, Indonesia

\section{A R T I C L E IN F O}

Article history:

Received July 06, 2021

Revised July 11, 2021

Accepted September 30, 2021

Available online November 25, 2021

\section{Kata Kunci:}

Pemetaan, Acara Televisi, Anak SD

Keywords:

Mapping, Television Programs, Elementary School Students

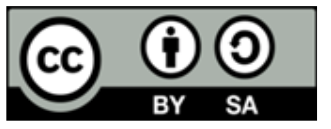

This is an open access article under the CC BY-SA license.

Copyright $(2021$ by Author. Published by Universitas Pendidikan Ganesha.

\begin{abstract}
A B S T R A K
Berbagai tayangan televisi saat ini dapat dengan mudah diakses oleh anak-anak selama 24 jam tanpa perlu adanya pendampingan orang tua. Tayangan televisi yang disajikan pun bermacam-macam jenisnya mulai dari tayangan edukasi, kartun sampai dengan sinetron. Artikel ini bertujuan untuk memetakan acara televisi yang digemari anak-anak Sekolah Dasar. Pendekatan utama penelitian ini adalah deskriptif kualitatif. Subjek penelitian ini adalah anak-anak Sekolah Dasar mulai dari kelas I sampai dengan kelas VI. Data penelitian ini dikumpulkan dengan menggunakan metode wawancara dan observasi. Analisis data penelitian ini menggunakan metode interaktif. Hasil penelitian ini menunjukkan acara televisi yang digemari anak-anak Sekolah Dasar meliputi: Spongebob, Upin \& Ipin, Kamen Rider Ex-Aid, Doraemon, Munki and Trunk, Si Bolang, On The Spot, Anak Langit, Tukang Ojek Pengkolan. Dapat disimpulkan bahwa acara televisi yang digemari anak-anak Sekolah Dasar adalah acara kartun yang memiliki daya imajinasi dan daya kreativitas. Perlu adanya pendampingan orang tua ketika anak menonton tayangan televisi terutama pada acara televisi yang di dalamnya terdapat unsur kekerasan maupun bullying.
\end{abstract}

\section{A B S T R A C T}

The various television shows can now be easily accessed by children for 24 hours without the need for parental controls. Television shows that are presented are of various types, ranging from educational shows, cartoons to soap operas. This article aims to map out television shows that are of favored by elementary school students. The approach of this research is qualitative descriptive. The subjects of this study were elementary school students from grade I to grade VI. The data of this study were collected by using interview and observation methods. The data analysis of this study used an interactive method. The results of this study shows that television shows that are of favored by elementary school students are: Spongebob, Upin \& Ipin, Kamen Rider Ex-Aid, Doraemon, Munki and Trunk, Si Bolang, On The Spot, Anak Langit, Tukang Ojek Pengkolan. It can be concluded that television shows that are favored by elementary school students are cartoon shows that have the power of imagination and creativity. There is a need for parental control when children watch television, especially on television shows in which the are elements of violence and bullying.

\section{INTRODUCTION}

The development of television shows is so dynamic and fast. It can be seen from the many diverse television shows presented to viewers, including programs offered to children like cartoons, motion animations, and pictures (Gever et al., 2021)(Kannass \& O'Toole, 2021). At least, children can watch a variety of television shows ranging from educational content, for example television shows in which there are informative, educative, recreational elements, and as a means of disseminating values to programs that damage children's morale, for example television shows in which there are elements of vulgarism, violence, and pornography on various private and national television stations (Artha, 2016; Salim et al., 2017). The implications of a good quality television show from language facilities and the values of character education offered to children will be able to make children better. Even further, television shows can be used as medium for character education and developing children's vocabulary, but conversely, if television shows offered to children are not good, it will potentially disrupt children's personal development and even lead 
to aggressive behavior (Atmoko et al., 2019; Chassiakos et al., 2016; Filisyamala, 2018; Lin et al., 2015). Television shows offered to children at least have positive and negative impacts (Hariyanto, 2018; Mariana, 2015). The positive impact of television shows for elementary school students can be used as a medium of learning, obtaining information, stimulating imagination, and creativity. However, television shows for school-aged children also have a negative impact, which makes children lazy to learn. This is in line, who stated that the intensity of children in watching television can affect children's discipline in obeying study time, even children find it difficult to get along with their friends because they tend to be closed (Agustina, 2016; Kaloka, 2017; Mardhani \& Fitriyani, 2016). The intensity of children in watching television can also affect worse sleep quality and negative effects on young children's executive function (Brockmann et al., 2016; Lillard \& Peterson, 2011). The positive and negative impacts caused by the television show need to be carried out in a study, what the television shows are suitable for elementary school students.

Elementary school students in watching television need to get parental guidance. Control and supervision is done so that parents provide understanding or knowledge to children about the program presented on the television shows has good values or not (Astarini et al., 2017; Fisnani et al., 2020; Huang et al., 2020). Television shows that are watched continuously will have an influence on the development of the child's personality. If the program presented does not exemplify good personality values, then children can imitate as the program presented. But on the contrary, if the television show presented contains personality values that are appropriate to the age level of the child, then the personality development of the child will also be good according to the level of maturity of the child's age. Television offers a variety of shows for viewers. Television shows are so diverse, both entertaining and educational, both for adults and for children, even in accordance with one's work such as business events. In addition, children also tend to love television shows that contain fantastic events (Li et al., 2021). Because of the diversity of television shows, children need to get parental guidance in enjoying television shows in order to get television shows that are beneficial. Children need to get guidance in watching television because the programs presented are not all suitable for the age of children. At least the television shows offered have two impacts, there are positive and negative impacts (Nurnisya, 2013; Raihan et al., 2020). Children in watching television shows must be guided and directed to watch television shows that have positive benefits.

The positive benefits or positive impacts of television shows if we explored further it can be used as media, models and an example of character education for children. Basically television shows have positive benefits without negating the negative impacts of television shows. The positive benefits of television shows include: educational messages (cognitive, affective, psychomotor aspects), creativity, knowledge of the use and operation of computers. Then, the negative impacts such as the amount of time spent watching television, the influence of violence from television shows, and aggressive behavior towards education (Rohani, 2015; Tarigan et al., 2016; Wahyuni, 2016). Therefore, the viewer needs to utilize the ability to take advantage of positive television shows (Astriani et al., 2014). Based on this, children need to get adult guidance to be able to take positive advantage of television shows. The need for adult's guidance in watching television doesn't mean to show that children are individuals who cannot take positive benefits from television shows. The guidance is carried out as an effort to anticipate because children are individuals who have the potential to erode the positive benefits of television. The results of previous study shows that parent's way in choosing television shows for children based on sources of parental knowledge and television show criteria (Trisiah, 2019; Wulandari \& Sarmini, 2017). The source of parental knowledge is based on previous television broadcasts and professional friends, while the criteria for the selected television shows are containing character education, according to the child's age, and the airtime is 4.00 p.m. to 5.30 p.m. Then, the results of previous study shows that the selection of television shows for children to watch based on criteria, namely television shows that contain elements of education, socio-cultural, can provide motivation to learn, and entertain (Khairina \& Amri, 2017; Sayekti, 2019). This is in line, who stated that child-friendly television programs are all programs ranging from viewing material to advertisements that contain children's world that can help five aspects of their development, namely moral-spiritual, cognitive, language, socio-emotional, and physical (Fadlurrohim et al., 2019; Hamzah et al., 2021).

It can be said that the characteristics of television shows for children include: first, children's programs are presented before time for sleep (not late at night), the contents of the message both audio and visual in accordance with the interests of children or according to the child's age. Second, television shows must contain character education. Third, television shows can provide students' motivation to learn. Fourth, television shows can help five aspects of child development (Fadlurrohim et al., 2019; Hamzah et al., 2021; Khairina \& Amri, 2017; Sayekti, 2019; Trisiah, 2019; Wulandari \& Sarmini, 2017). The criteria and the characteristics of television shows can be used as a guide to assess the quality of television shows that are suitable for elementary school students. The difference between this research and other research lies in the object of study. Several previous studies have focused on examining the correlation between television viewing and its effect on child development. The research in question is research conducted by (Aishworiya 
et al., 2019; Jolin \& Weller, 2011; Kostyrka-Allchorne et al., 2017; Ogelman et al., 2018). Meanwhile, in this research, the focus is on mapping television shows that are of favored by elementary school students. From the results of these studies can be found which television shows are suitable and not suitable for children. In order to fill the space that has not been much discussed, based on the description that has been presented above, the problems examined in this study focused on mapping television shows that are of favored by elementary school students. The problem is what television shows are of favored by elementary school students? In accordance with these problems, the purpose of this study is to map television shows that are of favored by elementary school students. The results of this study are used to determine which television programs are suitable for children, especially elementary school students..

\section{METHOD}

The approach of this research is qualitative descriptive. Qualitative descriptive is a research procedure that explores and understands the meaning individuals or groups ascribe to a social or human problem. Then, the process of this approach involves emerging questions and procedures, data typically collected in the participant's setting, data analysis inductively building from particulars to general themes, and the researcher making interpretations of the meaning of the data (Creswell, 2014). The qualitative descriptive approach in this study aims to produce a description of the data in the form of mapping television shows that are of favored by elementary school students. The data are in the form of words, sentences or paragraph, and dialogues in television shows that are of favored by elementary school students. In accordance with the type of research in qualitative research, the subject of this study is a description of the mapping of television shows that are of favored by elementary school students. Thus, the data used in this study are not numbers, but rather a description of the mapping of television shows that are of favored by elementary school students. The number of respondents in this study were 30 elementary school students in Hadirejo village and Denggungan village, Boyolali ranging from grade I to grade VI.

The data of this study were collected by interview and observation methods. Interview is a meeting of two people to exchange information and ideas through question and answer, so that meaning can be constructed in a particular topic (Sugiyono, 2017). While, observation is the process of gathering firsthand information by observing people and place at research site (Creswell, 2014). Some of the questions asked during the interview related to what television shows the children liked, the reasons why the children liked the television show, which characters the children liked and didn't like, the intensity of the children watching television, who accompanied the child to watch the television show, and whether the child imitates the behavior shown on the television show. The instrument in this study was the researcher itself. The validity test was carried out by researchers themselves through self-evaluation of how far their understanding of the qualitative method, the mastery of theory and insight into the fields studied, and the readiness of the researchers before conducting research. Then, the interviews in this study were conducted directly, it means that the researchers and respondents conducted question and answer session related to television shows that were favored by elementary school students in Boyolali. Interviews were conducted in a semi-structured and in-depth interview which was not only based on a list of questions that had been made, but questions could also be develop to explore more detailed and in-depth information. In order to focus the ongoing interviews and not expand on problems that are less related to the topic of this study, the researcher has anticipated it by making an agreement in advance about the topic that will be asked to the informant either directly. Then, observations in this study were carried out by observing television programs watched by elementary school students. Observation were used to verify the programs watched by elementary school students according to the results of interviews.

The data of this study were analyzed use an interactive method. Interactive analysis is an analytical process that has three components, namely: data reduction, data presentation, and drawing conclusions/verification which is carried out simultaneously or cyclically. Data reduction is a process of selecting, focusing, simplifying, and abstracting data that has been obtained from documents and informants. In this study, data reduction was carried out from the start of the initial process, namely before the researcher collected data. The data were selected and focused on television shows that are of favored by elementary school students. The data presentation is the central information in a study. In this study, the data presentation is in the form of a description of television shows that are of favored by elementary school students. Conclusions are drawn after going through the data reduction of the findings. Then, verification and conclusions are drawn. However, if in drawing conclusions it is still considered not significant, verification is carried out by tracing starting from data reduction and data presentation, thus this is a cycle. The interaction form of the components of data reduction, data presentation, drawing conclusions, and verification is carried out as part of the analysis process. This concluding cycle process was started by researchers from the beginning of data collection in the form of television shows that are of 
favored by elementary school students. The validity of the data in this study used the method triangulation. Method triangulation in this study was conducted by interview and observation method.

\section{RESULT AND DISCUSSION}

\section{Result}

The result of this study focus on mapping television shows that are of favored by elementary school students. The mapping of television shows that are of favored by elementary school students is important as an effort to provide guidance to children to watch television shows that have good quality and worth of character education. The result of the study are presented in table 1. Based on the calculation table above, there are nine television shows that elementary school students favor, namely the first is Spongebob shows that air from 11.00 a.m. to 4.00 p.m. with a percentage of $60 \%$. The second television shows that are of favored by elementary school students is Upin \& Ipin shows that air from 7.00 a.m. to 9.00 a.m. and 5.00 p.m. to 7.00 p.m. with a percentage of $14 \%$. The third television shows that are of favored by elementary school students is Kamen Rider Ex-Aid shows that air from 8.00 p.m. to 9.00 p.m. with a percentage of 7\%. The fourth television shows that are of favored by elementary school students is Doraemon shows that air from 8.00 a.m. to 9.00 a.m. with a percentage of $4 \%$. The fifth television shows that are of favored by elementary school students is Munki and Trunk shows that air from 5.00 a.m. to 6.30 a.m. with a percentage of $3 \%$. The sixth television shows that are of favored by elementary school students is Si Bolang shows that air from 12.30 p.m. to 1.00 p.m. with a percentage of 3\%. The seventh television shows that are of favored by elementary school students is On The Spot shows that air from 7.00 p.m. to 8.00 p.m. with a percentage of $3 \%$. The eighth television shows that are of favored by elementary school students is Anak Langit shows that air from $4.30 \mathrm{p} . \mathrm{m}$. to $6.30 \mathrm{p}$.m. with a percentage of $3 \%$. The ninth television shows that are of favored by elementary school students is Tukang Ojek Pengkolan shows that air from 6.45 p.m. to 9.15 p.m. with a percentage of $3 \%$. From the nine television shows that have been mentioned, the television show most favored by elementary school students is Spongebob.

Tabel 1. Television shows that are of favored by elementary school students

\begin{tabular}{clcc}
\hline No & \multicolumn{1}{c}{ Television Shows } & Airtime & Percentage \\
\hline 1. & Spongebob & 11.00 a.m. to 4.00 p.m. & $60 \%$ \\
2. & Upin \& Ipin & 7.00 a.m. to 9.00 a.m. & $14 \%$ \\
& & 5.00 p.m. to 7.00 p.m. & \\
3. & Kamen Rider Ex-Aid & 8.00 p.m. to 9.00 p.m. & $7 \%$ \\
4. & Doraemon & 8.00 a.m. to 9.00 a.m. & $4 \%$ \\
5. & Munki and Trunk & 5.00 a.m. to 6.30 a.m. & $3 \%$ \\
6. & Si Bolang & 12.30 p.m. to 1.00 p.m. & $3 \%$ \\
7. & On The Spot & 7.00 p.m. to 8.00 p.m. & $3 \%$ \\
8. & Anak Langit & 4.30 p.m. to 6.30 p.m. & $3 \%$ \\
9 & Tukang Ojek Pengkolan & 6.45 p.m. to 9.15 p.m. & $3 \%$ \\
\hline \multicolumn{2}{r}{ Total } \\
\hline
\end{tabular}

\section{Discussion}

Based on the result of the study presented in table 1, television shows that are of favored by elementary school students are varied, namely nine variations. The nine television shows certainly have their own characteristics. The following is a further explanation regarding television shows that are of favored by elementary school students. Spongebob is a television show that airs on Global TV at 11.00 a.m. to 4.00 p.m. Spongebob is a cartoon show with life figures under the sea, namely starfish, octopus, sea crabs, and fish. However, what is interesting besides the figures that are under the sea are several figures whose actual habitat is not at sea but on land. The figure in question is a squirrel even though the setting of the event is under the sea. This will certainly stimulate the imagination of children why squirrels can live under the sea. Based on the results of interviews with elementary school students, Spongebob shows is the most popular television show for elementary school students, which is 18 students or 60 percent. The reasons children love Spongebob television show because the unique characters and good stories. This finding is in line with (Panic et al., 2013; Suryadi, 2013; Tarr \& Brown, 2013) who stated that among the cartoons presented on the television show, Spongebob is the most watched program for children and a popular culture product that is able to attract children to adults to watch the program. Spongebob as a television show certainly has advantages and disadvantages. The advantages is Spongebob presents a good friendship. Then, the negative impact caused by Spongebob shows on children is that children become more hardhearted and can't concentrate or focus well (Hamzah et al., 2021; Nurnisya, 2013). This is in line with the 
findings found that children's television programs still contained violence, one of which was Spongebob (Rezeki, 2017; Syarief et al., 2013). In addition to the acts of violence presented in the show, other negative impact is the decline in learning achievement of elementary school students, namely a decrease in learning achievement by $7,24 \%$.

Upin \& Ipin is a television show in the form of cartoons that airs on MNC TV at 7.00 a.m. to 9.00 a.m and 5.00 p.m. to 7.00 p.m. The main characters in this television show are two twins and their friends. This program originated from Malaysia, it can be known by the language used, namely Malay. Based on the results of interviews with elementary school students, there are 4 students or 14 percent who like Upin \& Ipin shows. As for the reasons children love watching Upin \& Ipin shows because the program is funny and makes them excited, especially the characters Upin and Ipin who both have bald heads and one of the characters whose hair only grows in the middle and rises upwards. When we observed closely, Upin \& Ipin indeed present unusual programs like other cartoons. If other cartoons tell a lot about miracles and superheroes, Upin \& Ipin appear as simple as children who enjoy playing. When we viewed from the quality, Upin \& Ipin do have good quality for elementary school students because they present natural shows that are appropriate for the age of the children. This is in line with the findings from (Purnomo, 2016; Rahim et al., 2014; Sari et al., 2019). Upin \& Ipin show the lives of children who are enjoying their happy period, while also presenting the value of honest, loving each other's, respect, hardworking, and caring. Furthermore, there are many values of character education presented in Upin \& Ipin television shows and it can be used as a medium for building the values of character education in children. The values of character education include: religious, honest, tolerance, disciplined, hard work, creative, curiosity, respect for achievement, friendship, social care/fellow, responsibility, courage, cooperation, mutual help, wisdom, respect for life, politeness, respect for self, and patriotism. In addition, the dominant characters created in Upin \& Ipin shows are religious, honest, disciplined, and responsible characters (Untari \& Purnomo, 2016; Wulandari \& Sarmini, 2017).

Kamen Rider Ex-Aid is a television show that airs on RTV at 8.00 p.m. to 9.00 p.m. Kamen Rider ExAid is a television show originating from Japan that tells the story of several gamers who are doctors who can transform into Kamen Rider Ex-Aid while saving their patients from the Bugster virus. Bugster is a type of computer virus that is created from game software bug created by a company. This program when compared with Upin \& Ipin will look very different because Kamen Rider Ex-Aid tells the story of superheroes likes Superman or Ultraman. Based on the results of interviews with elementary school students, there are 2 students or 7 percent who like this shows. The students favored this program because it tells about superheroes. The respondent stated that "Kamen Rider Ex-Aid is a good program, because it's about warfare like Ultraman but he's a doctor". Even more clearly, other respondents stated that "Kamen Rider Ex-Aid tells the story of a doctor who treats patients by turning into Kamen Rider Ex-Aid to remove Bugster virus from the patient and he will get gashat when he wins". In addition to telling stories about superheroes, Kamen Rider Ex-Aid also presents fight scenes in each episode. Therefore, this program is not suitable for elementary school students because it contains elements of violence that are not good for child development. Children who watch violent shows are more likely to be rebellious, authoritarian and disapproving than children who do not watch violent shows (Mardiana, 2013). This is in line with the findings, violence program was lead to both short-term and long-term effects on the development of children's aggressive behavior (Christakis \& Zimmerman, 2007; Lan et al., 2010). Children who watch violence program during in early childhood was related the risk for antisocial and aggression at school age.

Doraemon is a television show that airs on RCTI at 8.00 a.m. to 9.00 a.m. Doraemon is an animated program originating from Japan with the main characters Doraemon and Nobita. Doraemon is a cat that has a variety of miracles, which is able to provide a variety of magical items from the magic pocket he has. Nobita is a friend of Doraemon who lives at home with Doraemon. Based on the results of interviews with elementary school students, there are 1 student or 4 percent who like this shows. The reason why elementary school students love Doraemon program is because the characters are cute especially Doraemon is the smart cat and Nobita is a child who likes to help his friends. Apart from being a character, the children loved this program because the story was funny and good. The stories in Doraemon represent the lives of children, namely happy playing, happy moving, whiny, and happy to imitate what is presented through the roundness of ideas and the characters in their activities also present good moral values, namely defending the truth, being helpful, and spoiled (Setyaningsih, 2019; Sihombing et al., 2016). This is in line, found that after watching Doraemon cartoon series, the impact of children's behavior is he understand the meaning of friendship with their friends and like to help each other (Basri, 2019; Rufeidah et al., 2018). This program also raise environmental issues so that humans love nature more. Apart from these positive things, there are negative things that are shown in this program, namely the scene of Giant fighting with Nobita which is not suitable for children to watch. Munki and Trunk is a television show that airs on ANTV at 5.00 a.m. to 6.30 a.m. Munki and Trunk are animated in the form of fables that the characters in this program are 
animals in the forest. Munki in this television show is a monkey, while the Trunk character is an elephant. The two characters are loyal friends, help each other, and in the story they are always together. Based on the results of interviews with elementary school students, there are 1 student or 3 percent who like this shows. The reason why children love Munki and Trunk shows is because the stories presented are able to attract the attention and interest of elementary school students. The respondent stated that "Because Munki and Trunk is good, then the nature of his friendship even though quarreling but still united". However, apart from showing the friendship between elephant and monkey, Munki and Trunk shows is not suitable for children's language development because it only displays images without sound or language and does not add to the child's insight. Then, Munki and Trunk's broadcast time is also too early. This also does not meet the criteria of television shows that are suitable for children according to the results of the study (Hamzah et al., 2021; Syarah et al., 2018; Wulandari \& Sarmini, 2017).

Si Bolang is a television show that airs on Trans 7 at 12.30 p.m. to 1.00 p.m. Si Bolang is a program that is not animated so the characters who play in this program are children not animation. Si Bolang is a television show that is presented to the viewers by presenting stories in the form of children's adventures, such as at sea, forest, rice fields, and so on. In other words, Si Bolang's program presents a variety of local wisdom in Indonesia. Besides Si Bolang, Trans7 also presents other television shows, including: Laptop Si Unyil, Si Unyil Keliling Dunia, Dunia Binatang, and Jejak Petualang. From some of these television shows, the children prefer Si Bolang's program which had an adventure genre. Although Jejak Petualang's program also tells the story of adventure, children don't like it much, this is because the program is more suitable for adults to watch because the adventure that airs is more challenging and the players are also adults. Based on the results of interviews with elementary school students, there are 1 student or 3 percent who like $\mathrm{Si}$ Bolang. The reason why the children watch Si Bolang is because the program has creative and adventure value. The intended creative value is to be able to take advantage of various things that are around the neighborhood, for example: making shoots from bamboo, making ships from orange peels, and various other products. This is in line with the findings found that Si Bolang show affects students' creativity (Solifah et al., 2020b, 2020a). In addition to being able to develop ideas and solve problems encountered when experiencing difficulties, students can also communicate what they know to their friends or parents.

On The Spot is a television show that airs on Trans 7 at 7.00 p.m. to 8.00 p.m. On The Spot is the program that presents a variety of information. The information shared is interesting information both from within the country and abroad that can add insight to those who watch it. On The Spot presents a variety of information that is summarized in certain episodes that occur in various regions and even in various countries. Based on the results of interviews with elementary school students, there are 1 student or 3 percent who like On The Spot. The reason why elementary school students love On The Spot shows because the information is interesting and sometimes tells scary things. This is in line with the findings stated that television shows that is often chosen by parents to watch with their children and presents unique information from various parts of the world is On The Spot (Amalia, 2014; Khairina \& Amri, 2017; Telengkeng, 2014). This is because parents feel that the program can add insight and knowledge. However, this program does not meet the criteria of television shows that are suitable for children because the broadcast time are night and can interfere with children's learning time. Anak Langit is a television show that airs on SCTV at 4.30 p.m. to 6.30 p.m. Anak Langit is a soap opera that tells the life of the club and motorcycle gangs. There are two characters serving, namely a good motorcycle club likes to help and motorcycle gangs who have evil characters like to fight, make a fuss and so on. Based on the results of interviews with elementary school students, there are 1 student or 3 percent who like this shows. The reason why elementary school students love Anak Langit's program is because the story is good. In addition, there is a main character who is a favorite of children, namely a character named Hiro because he is kind and helpful. However, if it is examined further, although it presents a good and helpful motorcycle club in its shows, it also presents many stories that are actually not appropriate to be aired. There are several scenes of violence and not appropriate for children and adolescents to watch, for example rude expressions to older people, insulting expressions of social status and origins, scenes of fighting and beatings (Azwar et al., 2019; Matau \& Ghofur, 2019). Therefore, this program is not suitable for elementary school students because it contains elements of violence that are not good for child development. The findings show that watching violent shows will have an effect on the development of aggressive behavior and empathy of school children (Coyne, 2016; Krahé \& Möller, 2010; Lan et al., 2010).

Tukang Ojek Pengkolan is a television show that airs on RCTI at 6.45 p.m. to 9.15 p.m. Tukang Ojek Pengkolan tells about the motorcycle taxis driver in Rawa Bebek, the motorcycle taxis driver are Ojak, Purnomo, and Tisna. Tukang Ojek Pengkolan's program can be said that the program succeeded in capturing the interest of the viewers to always watch. The success of Tukang Ojek Pengkolan because of the drama program format that is able to attract the viewer's interest (Munanjar \& Kusumawati, 2019). Besides Tukang Ojek Pengkolan, there are also soap operas that air on RCTI, namely Reverse World (Dunia 
Terbalik). Dunia Terbalik's program has similarities with Tukang Ojek Pengkolan, which is a soap opera that is packaged in a relaxed style unlike ordinary soap operas. However, elementary school students prefer Tukang Ojek Pengkolan because of its earlier broadcast time than Dunia Terbalik. Based on the results of interviews with elementary school students, there are 1 student or 3 percent who like this shows. The reason why elementary school students love Tukang Ojek Pengkolan's program because the story is funny, interesting, and exciting. The character he likes in Tukang Ojek Pengkolan shows is Tisna because Tisna likes to help Pur. Meanwhile, the character he doesn't like is Pur. The respondent revealed that he did not like Pur because character of Pur liked to lie. Lying is meant when Pur's character is sick, he actually lies so that Tisna's character helps him. However, this program does not meet the criteria of television shows that are suitable for children according to the results of the study (Trisiah, 2019; Wulandari \& Sarmini, 2017) because the broadcast time are night and the program is not appropriate for the child's age.

Television shows presented for children must meet several criteria. The criteria and the characteristics of television shows for children, include: children's programs are presented before time for sleep (not late at night), the contents of the message both audio and visual in accordance with the interests of children or according to the child's age; television shows must contain character education; television shows can provide students' motivation to learn; television shows can help five aspects of child development (Fadlurrohim et al., 2019; Hamzah et al., 2021; Khairina \& Amri, 2017; Sayekti, 2019; Trisiah, 2019; Wulandari \& Sarmini, 2017). Based on these criteria, it can be concluded television shows that are suitable for elementary school students are Upin \& Ipin and Si Bolang. In addition to entertaining, Upin \& Ipin and Si Bolang shows also affect the moral development and creativity of elementary school students. This is reinforced by research that has been conducted stated that Upin \& Ipin shows contain several moral values that affect the moral development of elementary school students, namely a sense of democracy, courage, cooperation, concern with others, help, respect, obedience, tolerance, giving and returning greetings, being honest, sharing, forgiving each other (Hariandi et al., 2020; Risdiany \& Lestari, 2021). Then, the research that has been conducted also stated that Si Bolang shows are able to affect student's creativity, able to develop their ideas and solve problems encountered when experiencing difficulties, and able to increase students' awareness of their friends (Solifah et al., 2020a). From this explanation, Upin \& Ipin and Si Bolang shows contain many values that can serve as role models for children. It is hoped that the two television shows can be used as a reference by parents in choosing television shows that are appropriate for the age of their children.

\section{CONCLUSION}

The television shows that are most favored by elementary school students are cartoon shows that have the power of imagination and creativity. This can be seen from the various types of television shows that are of favored by elementary school students and the number of respondents who like them. From the nine television shows that are of favored by elementary school students, there are two television shows that are suitable for elementary school students based on the criteria of television shows for children's age and child development, namely Upin \& Ipin and Si Bolang. In addition, parents also need to provide assistance to their children while watching television, especially on television shows in which there are elements of violence and bullying. The role of parents are needed so that children do not imitate the negative scenes in the television shows they watch.

\section{REFERENCES}

Agustina, D. (2016). Pengaruh Intensitas Menonton Televisi Terhada Kedisiplinan Anak Dalam Membagi Waktu Belajar Di MIN 2 Model Samarinda. Jurnal Ilmu Komunikasi, 4(3), 305-319. https: //ejournal.ilkom.fisip-unmul.ac.id/site/?p=2616.

Aishworiya, R., Cai, S., Chen, H. Y., Phua, D. Y., Broekman, B. F. P., Daniel, L. M., Chong, Y. S., Shek, L. P., Yap, F., Chan, S. Y., Meaney, M. J., \& Law, E. C. (2019). Television viewing and child cognition in a longitudinal birth cohort in Singapore: The role of maternal factors. BMC Pediatrics, 19(1), 1-8. https://doi.org/10.1186/s12887-019-1651-z.

Amalia, R. (2014). Efek Tayangan on the Spot Terhadap Pesan Media Massa Bagi Mahasiswa Ilmu Komunikasi Universitas Mulawarman. E-Journal Ilmu Komunikasi, 3(2), 30-42.

Artha, D. J. (2016). Pengaruh Pemilihan Tayangan Televisi Terhadap Perkembangan Sosialisasi Anak. EduTech: Jurnal Ilmu Pendidikan Dan Ilmu Sosial, 2(1), 18-26. https://doi.org/10.30596\%2Fedutech.v2i1.573.

Astarini, N., Hamid, S. I., \& Rustini, T. (2017). Studi Dampak Tavangan Televisi Terhadap Perkembangan Perilaku Sosial Anak. Cakrawala Dini: Jurnal Pendidikan Anak Usia Dini, 8(1). 
https://doi.org/10.17509/cd.v8i1.10554.

Astriani, A. S., Supratman, D., \& Pristiwati, R. (2014). Pengaruh Kebiasaan Menonton Televisi Acara Informasi dan Pergaulan Teman Sebaya Terhadap Keterampilan Berbicara Siswa Kelas VIII MTs NU Ungaran. Jurnal Pendidikan Bahasa Dan Sastra Indonesia, 3(1). https://doi.org/10.15294/jpbsi.v3i1.4002.

Atmoko, A. D., Munir, Z., \& Ramadhan, G. (2019). Pengaruh Menonton Tayangan Televisi Terhadap Perilaku Agresif Pada Anak Prasekolah. Jurnal Keperawatan Profesional (JKP), 7(1). https://doi.org/10.33650/jkp.v7i1.509.

Azwar, Shanti, H. D., \& Arumdhani, K. (2019). Dampak Sinetron Indonesia terhadap Perilaku Masyarakat (Analisis Kasus: Sinetron Anak Langit Di Sctv). Journal of Digital Education, Communication, and Arts (DECA), 2(2), 89-98. https://doi.org/10.30871/deca.v2i02.1524.

Basri, S. Q. (2019). Studi Ecocriticism dalam Film Doraemon \& Nobita and The Green Giant Legend Karya Ayumu Watanabe. SOSIOHUMANIORA: Jurnal Ilmiah Ilmu Sosial Dan Humaniora, 5(1), 89-101. https://doi.org/10.30738/sosio.v5i1.2862.

Brockmann, P. E., Diaz, B., Damiani, F., Villarroel, L., Nunez, F., \& Bruni, O. (2016). Impact of television on the quality of sleep in preschool children. Sleep Medicine, 20, 140-144. https://doi.org/10.1016/j.sleep.2015.06.005.

Chassiakos, Y. R., Radesky, J., Christakis, D., Moreno, M. A., Cross, C., Hill, D., Ameenuddin, N., Hutchinson, J., Boyd, R., Mendelson, R., Smith, J., \& Swanson, W. S. (2016). Children and adolescents and digital media. Pediatrics, 138(5). https://doi.org/10.1542/peds.2016-2593.

Christakis, D. A., \& Zimmerman, F. J. (2007). Violent television viewing during preschool is associated with antisocial behavior during school age. Pediatrics, 120(5), 993-999. https://doi.org/10.1542/peds.2006-3244.

Coyne, S. M. (2016). Effects of viewing relational aggression on television on aggressive behavior in adolescents: A three-year longitudinal study. Developmental Psychology, 52(2), 284-295. https://doi.org/10.1037/dev0000068.

Creswell, J. W. (2014). Research Design: Qualitative, Quantitative, and Mixed Methods Approaches (Fourth Edition). United States of America: SAGE Publications.

Fadlurrohim, I., Husein, A., Yulia, L., Wibowo, H., \& Raharjo, S. T. (2019). Memahami Perkembangan Anak Generasi Alfa Di Era Industri 4.0. Focus: Jurnal Pekerjaan Sosial, 2(2), 178-186. https: //doi.org/10.24198/focus.v2i2.26235.

Filisyamala, J. (2018). Pengaruh Media Televisi untuk Mengembangkan Kosakata Anak. Briliant: Jurnal Riset Dan Konseptual, 3(2), 253-259. https://doi.org/10.28926/briliant.v3i2.180.

Fisnani, Y., Utanto, Y., \& Ahmadi, F. (2020). The Development of E-Module for Batik Local Content in Pekalongan Elementary School. Innovative Journal of Curriculum and Educational Technology, 9(1), 40-47. https://doi.org/10.15294/IJCET.V9I1.35592.

Gever, V. C., Tunca, E. A., Boluwatife, A. A., Nwogbo, V. C., \& Chinweobo-Onuoha, B. N. (2021). Visual media and learning: Effect of interactive television instruction as an intervention strategy for improving the critical thinking skills and disposition of out-of-school nomadic children in Nigeria. Learning and Motivation, 76. https://doi.org/10.1016/j.lmot.2021.101767.

Hamzah, N., Khomaeny, E. F. F., \& Ulfa, M. (2021). Tontonan anak di Televisi: Paradoks dan Kontestasi Nilai Tontonan Anak di Media Televisi Nasional. Jurnal Obsesi : Jurnal Pendidikan Anak Usia Dini, 5(2), 1883-1893. https://doi.org/10.31004/obsesi.v5i2.713.

Hariandi, A., Rahmayanti, W., Wati, N., Syafia, Y. M., \& Valensy, D. A. (2020). Moral Analysis in the Animated Films of Nusa Rara and Upin Ipin as Educational Shows. AL-ISHLAH: Jurnal Pendidikan, 12(2), 465480. https://doi.org/10.35445/alishlah.v12.i2.220.

Hariyanto, F. (2018). Peran Orang Tua dalam Membimbing Anak Menonton Acara Televisi. Jurnal Politikom Indonesiana, 3(2), 179-186. https://doi.org/10.35706/jpi.v3i2.1665.

Huang, S.-Y., Kuo, Y.-H., \& Chen, H.-C. (2020). Applying Digital Escape Rooms Infused with Science Teaching in Elementary School: Learning Performance, Learning Motivation, and Problem-Solving Ability. Journal Pre-Proof, 1(1), 1-46. https://doi.org/10.1016/j.tsc.2020.100681.

Jolin, E. M., \& Weller, R. A. (2011). Television viewing and its impact on childhood behaviors. Current Psychiatry Reports, 13, 122-128. https://doi.org/10.1007/s11920-011-0175-5.

Kaloka, R. A. (2017). Parental Mediation Pada Anak Saat Menonton Televisi Dengan Rating Guide Bimbingan Orang Tua (R-Bo). Interaksi: Jurnal Ilmu Komunikasi, 5(1), 62-67. https://doi.org/10.14710/interaksi.5.1.62-67.

Kannass, K. N., \& O’Toole, K. J. (2021). Background television and distractibility in young children: Does program content matter? Journal of Applied Developmental Psychology, 75. https://doi.org/10.1016/j.appdev.2021.101280. 
Khairina, \& Amri, A. (2017). Preferensi Orang Tua Terhadap Tayangan Edukatif di Televisi Dalam Pendampingan Anak MenontonTelevisi (Studi Terhadap Orang Tua di Gampong Lamteungoh Kecamatan Ingin Jaya Aceh Besar). Jurnal Ilmiah Mahasiswa (JIM), 2(4), 144-156. http://www.jim.unsyiah.ac.id/FISIP/article/view/5446.

Kostyrka-Allchorne, K., Cooper, N. R., \& Simpson, A. (2017). The relationship between television exposure and children's cognition and behaviour: A systematic review. Developmental Review, 44, 19-58. https://doi.org/10.1016/j.dr.2016.12.002.

Krahé, B., \& Möller, I. (2010). Longitudinal effects of media violence on aggression and empathy among German adolescents. Journal of Applied Developmental Psychology, 31(5), 401-409. https://doi.org/10.1016/j.appdev.2010.07.003.

Lan, K. L., Abdullah, M. C., \& Roslan, S. (2010). Understanding media violence and the development of aggressive behaviour of school children. Procedia - Social and Behavioral Sciences, 7(2), 522-527. https://doi.org/10.1016/j.sbspro.2010.10.070.

Li, Y., Wang, Y., Chen, X., Li, S., \& Zhang, L. (2021). Do children know that fantastic events in television programs are not real? Cognitive Development, 58. https://doi.org/10.1016/j.cogdev.2021.101020.

Lillard, A. S., \& Peterson, J. (2011). The immediate impact of different types of television on young children's executive function. Pediatrics, 128(4), 644-649. https://doi.org/10.1542/peds.2010-1919.

Lin, L.-Y., Cherng, R.-J., Chen, Y.-J., Chen, Y.-J., \& Yang, H.-M. (2015). Effects of television exposure on developmental skills among young children. Infant Behavior and Development, 38, 20-26. https://doi.org/10.1016/j.infbeh.2014.12.005.

Mardhani, V., \& Fitriyani, P. (2016). Perilaku Menonton Televisi Dan Perkembangan Anak Usia Sekolah Menurut Persepsi Ibu. Jurnal Keperawatan, 8(1), 14-19. https: //doi.org/10.32583/keperawatan.8.1.2016.14-19.

Mardiana, S. (2013). Kekerasan Di Televisi dan Perkembangan Anak. LONTAR: Jurnal Ilmu Komunikasi, 2(1), 48-54. https://doi.org/10.30656/lontar.v2i1.277.

Mariana, E. R. (2015). Aspek Positif Dan Negatif Tayangan Televisi Terhadap Anak. Al 'Ulum, 65(3), 54-59.

Matau, B. J., \& Ghofur, M. A. (2019). Bentuk Kekerasan Pada Sinetron Anak Langit. Jurnal Komunikasi Nusantara, 1(1), 51-57. https://doi.org/10.33366/jkn.v1i1.14.

Munanjar, A., \& Kusumawati, N. (2019). Keberhasilan Format Program Drama dalam Menjaring Penonton Televisi ( Studi Kasus Sinetron Ojek Pengkolan RCTI ). Jurnal Ilmu Komunikasi (J-KIA), 6(1), 43-50. https://doi.org/10.31294/kom.v6i1.6212.

Nurnisya, F. Y. (2013). Melek Media : Strategi Pencegahan Pengaruh Buruk Media Televisi pada Anak-anak. Jurnal Komunikator, 5(1), 21-27.

Ogelman, H. G., Gungor, H., Korukcu, O., \& Sarkaya, H. E. (2018). Examination of the relationship between technology use of 5-6 year-old children and their social skills and social status. Early Child Development and Care, 188(2), 168-182. https://doi.org/10.1080/03004430.2016.1208190.

Panic, K., Cauberghe, V., \& De Pelsmacker, P. (2013). Comparing TV Ads and Advergames Targeting Children: The Impact of Persuasion Knowledge on Behavioral Responses. Journal of Advertising, 42(2-3), 264-273. https://doi.org/10.1080/00913367.2013.774605.

Purnomo, F. S. (2016). Analisis Nilai - Nilai Pendidikan Karakter dalam Film Upin dan Ipin Produksi Les Copaque Tahun 2010. Diksa: Pendidikan Bahasa Dan Sastra Indonesia, 2(2), 142-149. https://doi.org/10.33369/diksa.v2i2.3411.

Rahim, N. A., Halim, H. A., \& Mamat, R. (2014). Learning via television cartoon. Asian Social Science, 10(15), 8-15. https://doi.org/10.5539/ass.v10n15p8.

Raihan, F., Rachman, F., Gita Saputra, I., \& Iqbal Afghan, M. (2020). Pengaruh Tayangan Kartun di TV Terhadap Kemampuan Bersosialisasi Anak. Communications, 2(1), 51-66. https://doi.org/10.21009/communications.2.1.4.

Rezeki, U. S. (2017). Pengaruh Menonton Film Kartun Spongebob Squarepant di Televisi terhadap Prestasi Belajar Bahasa Indonesia Siswa Kelas V SD Negeri 067952 Medan Johor. Jurnal Curere, 01(01), 5670. https://doi.org/10.36764/jc.v1i1.23.

Risdiany, H., \& Lestari, T. (2021). Pengaruh Film Kartun Upin Dan Ipin Terhadap Perkembangan Moral Anak. Edukatif: Jurnal Ilmu Pendidikan, 3(4), 1366-1372. https://doi.org/10.31004/edukatif.v3i4.577.

Rohani, G. A. (2015). Pengaruh Televisi (Tv) Terhadap Aspek-Aspek Perkembangan Anak Usia 3-4 Tahun. Jurnal Pendidikan Anak, 4(2), 631-639. https://doi.org/10.21831/jpa.v4i2.12355.

Rufeidah, A., Saad, S., \& Kadir. (2018). Evaluasi Program Televisi Pendidikan “Kartun Anak." Jurnal Sekretari, 5(2), 1-12. https://doi.org/10.32493/skr.v5i2.1577.

Salim, N. A., Afdal, \& Handayani, E. S. (2017). Peran Tayangan Adit Sopo Jarwo (ASJ) Terhadap Pendidikan Karakter Anak Sekolah Dasar Di Kabupaten Kutai Kartanegara (Studi Kasus Pada SDN 008 Muara Jawa). Jurnal Pendas Mahakam, 2(1), 72-82. https://jurnal.fkip- 
uwgm.ac.id/index.php/pendasmahakam/article/view/94.

Sari, A. L., Nariyah, H., \& Wihayati, W. (2019). Studi Fenomenologi Film Animasi Upin dan Ipin di MNC TV dalam Membentuk Perilaku Imitasi pada Anak di TK Al-Muhibbin Kecamatan Sumber Kabupaten Cirebon. Jurnal Signal, 7(1), 15-26. https://doi.org/10.33603/signal.v7i1.1915.

Sayekti, O. M. (2019). Film Animasi “Nussa dan Rara Episode Baik Itu Mudah” sebagai Sarana Penanaman Karakter pada Anak Usia Dini. Jurnal Pendidikan Anak, 8(2), 164-171. https://doi.org/10.21831/jpa.v8i2.29093.

Setyaningsih, F. D. (2019). Representasi Anak-Anak Melalui Komik Doraemon Berdasarkan Pendekatan Image System. Jurnal Komunikasi, 11(1), 42-51. https://doi.org/10.24912/jk.v10i1.2472.

Sihombing, A., Muzakka, M., \& Fadli, Z. A. (2016). Penggambaran Karakter Tokoh Utama pada Komik Doraemon Karya Fujiko F Fujio. Jurnal Japanese Literature, 2(2), 1-9.

Solifah, P., Prasetya, S. A., \& Reffiane, F. (2020a). Program TV Bocah Petualang Tema Pegunungan Sebagai Pemantik Kreativitas Berkarya Anak. Jurnal Penelitian Dan Pengembangan Pendidikan, 4(3), 472478. https://doi.org/10.23887/jppp.v4i3.27146.

Solifah, P., Prasetya, S. A., \& Reffiane, F. (2020b). Program TV Bocah Petualang Tema Pegunungan sebagai Pematik Kreativitas Berkarya Anak SDN Peterongan Semarang. Widya Wacana: Jurnal Ilmiah, 15(2), 93-101. https://doi.org/10.33061/j.w.wacana.v15i2.3894.

Sugiyono. (2017). Metode Penelitian Kuantitatif, Kualitatif, dan R\&D. Alfabeta.

Suryadi, I. (2013). Kajian Perilaku Menonton Tayangan Televisi dan Pendidikan Literasi Media pada Remaja. Academica, $5(1)$, 973-986. http://jurnal.untad.ac.id/jurnal/index.php/academica/article/view/2261.

Syarah, M. M., Sinta, M. R., \& Komariah. (2018). Pencegahan Pengaruh Negatif Siaran Televisi Terhadap Anak-Anak. JURNAL ABDIMAS BSI: Jurnal Pengabdian Kepada Masyarakat, 1(3), 434-445. https://doi.org/10.31294/jabdimas.v1i3.4058.

Syarief, L., Saparwati, M., \& Mawardika, T. (2013). Hubungan Kebiasaan Menonton Tayangan Kekerasan di Televisi dengan Perilaku Agresif pada Anak Pra Sekolah di TK Islam Terpadu Al Akhyar Kabupaten Kudus. Jurnal Keperawatan Anak Persatuan Perawat Nasional Indonesia, 1(2), 91-98. https://jurnal.unimus.ac.id/index.php/JKA/article/view/966.

Tarigan, T., Ervani, N., \& Lubis, S. (2016). Pola Menonton Televisi dan Pengaruhnya Terhadap Anak. Sari Pediatri, 9(1), 44-47. https://doi.org/10.14238/sp9.1.2007.44-7.

Tarr, B. A., \& Brown, T. J. (2013). Of Theory and Praxis : SpongeBob SquarePants and Contemporary Constructions of the American Dream. American International Journal of Contemporary Research, 3(11), 20-29. http://www.aijcrnet.com/journals/Vol_3_No_11_Novembe_2013/3.pdf.

Telengkeng, H. (2014). Motif Penonton Perempuan Surabaya dalam Menonton Program Televisi “ On The Spot " di Trans7. Journal E-Komunikasi, 2(3), 1-8. http://publication.petra.ac.id/index.php/ilmukomunikasi/article/view/3789/3566.

Trisiah, A. (2019). Dampak Tayangan Televisi Pada Pola Komunikasi Anak. Jurnal Inovasi, 13(1), 34-45. https://doi.org/10.33557/jurnalinovasi.v13i1.609.

Untari, M. F. A., \& Purnomo, F. U. (2016). Kajian Nilai Moral Dalam Film Kartun Upin Dan Ipin Edisi "Ikhlas Dari Hati” Produksi Les' Copaque. Malih Peddas (Majalah Ilmiah Pendidikan Dasar), 6(1), 9-18. https://doi.org/10.26877/malihpeddas.v6i1.1113.

Wahyuni, S. (2016). Peran Orang Tua terhadap Anak dalam Menonton Televisi yang Bermanfaat Bagi Perkembangan Moral Anak. Jurnal Ilmiah Guru “COPE,” 20(02), 73-80. https://journal.uny.ac.id/index.php/cope/article/view/13046.

Wulandari, E. M., \& Sarmini. (2017). Konstruksi Orang Tua Terhadap Pemilihan Acara Televisi Untuk Membentuk Karakter Anak Di Desa Jumputrejo Kecamatan Sukodono Kabupaten Sidoarjo. Kajian Moral Dan Kewarganegaraan, $\quad$ 5(02), https://jurnalmahasiswa.unesa.ac.id/index.php/index/index. 